\title{
EVALUATION OF SOME MANAGEMENT STRATEGIES IN EUTROPHIC MOGAN LAKE, TURKEY: PHOSPHORUS MOBILITY IN THE SEDIMENT-WATER INTERFACE
}

\author{
TOPÇU, A. - PULATSÜ, S. \\ Ankara University, Agricultural Faculty, Department of Fisheries and Aquaculture \\ Engineering, Ankara, Turkey \\ (e-mail: spulatsu@agri.ankara.edu.tr; tel:+90-3-125-961-648; fax: +90-3-123-185-298) \\ *Corresponding author \\ e-mail:topcu@ankara.edu.tr \\ (Received $31^{\text {st }}$ May 2017; accepted $2^{\text {nd }}$ Aug 2017)
}

\begin{abstract}
Mogan Lake, a popular recreation area, is under the pressure of intense urban-industrial pollution, therefore some management strategies included occasional macrophyte harvesting, diverting running water into the lake to accelerate the improvement of its water, and dredging have been in progressing since 1995 . This study was conducted on sediment and overlying water samples collected in April, July and October 2015 and January 2016 from Mogan Lake. The outstanding data for this study is presented as: i) detection of the sediment chemical composition and estimation of sediment phosphorus mobility, ii) comparison of the current status of the lake's eutrophication regarding phosphorus mobility with data from earlier studies regarding the common station. The research data has revealed i) sediment TP concentrations ranged from $620.00 \mu \mathrm{gP} \mathrm{gDW}^{-1}$, to $1047.50 \mu \mathrm{gP} \mathrm{gDW}^{-1}$ while $\mathrm{TN}$ concentrations were between $3250.00 \mu \mathrm{g} \mathrm{gDW}^{-1}$ and $6325.00 \mu \mathrm{g} \mathrm{gDW}^{-1}$. Sediment TOC concentrations ranged between $58850.00 \mu \mathrm{g} \mathrm{gDW}^{-1}$ and $79675.00 \mu \mathrm{g}$ $\mathrm{gDW}^{-1}$. Sediment iron content and loss on ignition values were determined as 1.608-3.415 mg gDW $\mathrm{gD}^{-1}$ and 9.05-20.94\%, respectively. The rank order of phosphorus fractions were evaluated as $\mathrm{Ca} \approx \mathrm{P}>\mathrm{Org} \approx \mathrm{P}>\mathrm{CO}_{3} \approx \mathrm{P}>\mathrm{Fe}+\mathrm{Al} \approx \mathrm{P}$. ii) the phosphorus release values from the sediment $(0.1754-1.1249 \mathrm{mg}$ $\mathrm{P} \mathrm{m}^{-2} \mathrm{~d}^{-1}$ ) were higher than the earlier studies findings. Phosphorus release in the lake has increased over the past ten years but still remains at a generally low level together with some management activities in Mogan Lake, therefore, instead of the internal P source future research should focus on external sources. In shallow eutrophic systems such as Mogan Lake, sediments having phosphorus accumulation depends on deep interactions with principally antropogenic external sources. In conclusion the primary goal is to determine the adsorption capacity of the sediment in order to estimate the critical internal phosphorus load and the second goal should be to apply a sustainable monitoring program.
\end{abstract}

Keywords: freshwater, phosphorus speciation, eutrophication, lake management, nutrient cycle

\section{Introduction}

The primary gauge of the phosphorus cycle in natural freshwater bodies is the shift of phosphorus between the sediment and the overlying water. Better understanding of the occurrence of water phosphorus $(\mathrm{P})$ at the water-sediment interface is vital to clarify $\mathrm{P}$ sources of origin in freshwater shallow lake ecosystems (Pu et al., 2017). Rather than focusing on total phosphorus content when examining the relationship between sediment phosphorus and eutrophication in a lake, it is more efficient to focus on the contents of the different phosphorus fractions (Christophoridis and Fytianos, 2006). The critical roles of $\mathrm{P}$ fractionation as regulators were manifested to interpret immediate and hysteretic internal liberation and indirectly represent anthropogenic inputs ( $\mathrm{Pu}$ et al., 2017). In determining the sediment's role as either a trap or a source of phosphorus, it is important to use chemical extractions to examine different chemical $\mathrm{P}$ fractions in the sediment such as labile $\mathrm{P}$, reductant $\mathrm{P}$, metal-bound $\mathrm{P}$, occluded $\mathrm{P}$ and organic $\mathrm{P}$ (Smolders et al., 2006). 
The accumulation of phosphorus in lake sediment generally occurs during heavy loading cycles, and its release into the overlying water is seen prior to reductions in external loading (Jiang and Shen, 2006; Watson et al., 2016). Several physical, chemical and biological measures (biomanipulation, phosphate inactivation, rooted macrophyte harvesting and sediment dredging) are generally undertaken in lakes to control eutrophication caused by internal phosphorus loading, which can be triggered by a reduction of external phosphorus loading (Smolders et al., 2006; Madura and Goldyn, 2009).

Several studies (Pulatsü et al., 2008; Topçu and Pulatsü, 2008; Pulatsü and Topçu, 2009) have been undertaken regarding the eutrophication-sediment interaction in Mogan Lake, which is an important recreation area due to its proximity to Ankara. Mogan Lake was chosen in this study due to the fact that it has been heavily influenced by human actions ranging from agricultural and domestic to semi-industrial pollution sources. Furthermore, it is thought that the data collected from the study will be of importance for the management of the lake, and these data could also be useful in the management of similar aquatic systems.

The first measures aimed at reducing external pollution loads in this shallow, eutrophic lake, located in the Gölbaşı Special Protected Area and under the pressure of intense urban-industrial pollution, were begun in 1995. These management strategies included occasional macrophyte harvesting, diverting running water into the lake to accelerate the improvement of its water, and dredging. The aim of this study was to give an overview in April, July, and October 2015 and January 2016 following the implementation of these management strategies in Mogan Lake including i) detection of the sediment chemical composition (total organic carbon, loss on ignition, total iron, total nitrogen, total phosphorus and phosphorus fractions), and determination of sediment-sediment overlying water phosphorus mobility (sediment phosphorus release/retention) with effective factors in a view towards phosphorus control and ii) comparison of the current status of the lake's eutrophication regarding phosphorus mobility with some earlier study data (Topçu and Pulatsü, 2008; Pulatsü et al., 2009) considering the common station.

\section{Materials and Method}

\section{Study site}

Mogan Lake, located $20 \mathrm{~km}$ south of Ankara, Turkey $\left(39^{\circ} 47^{\prime} \mathrm{N} 32^{\circ} 47^{\prime} \mathrm{E}\right)$, is an alluvial pond that is fed by more than five streams of varying size. The lake's outflow is into Eymir Lake through a wetland on Mogan's north side. Mogan Lake's surface area is $7.20 \mathrm{~km}^{2}$, its mean depth is $2.80 \mathrm{~m}$, its lake volume is $13.72 \times 106 \mathrm{~m}^{3}$, and its average theoretical flushing rate is 1.35 times per year (Boşgelmez et al., 2005). Due to the external phosphorus load resulting from detergents in waste water effluents and fertilizers in agricultural run-off from nearby areas, Mogan Lake is highly eutrophic (Fakığlu and Pulatsü, 2005). Because the bed of the eastern littoral area of Mogan Lake is covered by stone, two research stations were established near the lake's western shore, where the lake bed is more suitable for obtaining sediment samples. There were rooted surface plants in the areas surrounding the stations, and the western shore of the lake is affected by dense development and exposed to anthropogenic pollutants. The research area and location of the stations are shown in Figure 1. 


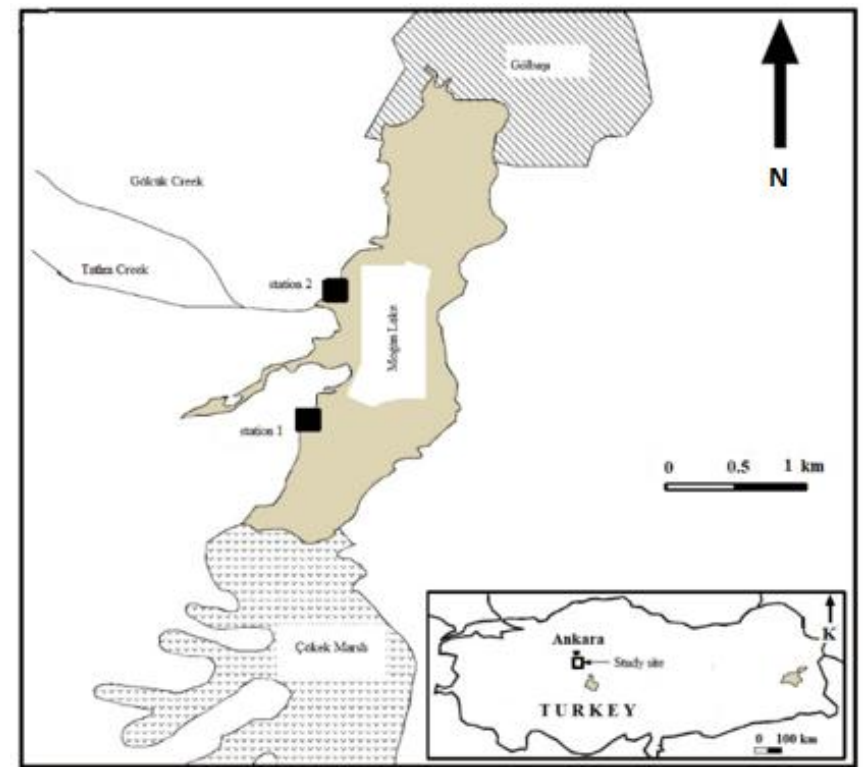

Figure 1. Map of the lake Mogan with the sampling site (-)

\section{Field work}

Three independent parallel sediment samples were collected from $70 \mathrm{~cm}$ of the littoral zone in the north-western part of the lake in April, July and October 2015 and January 2016 using Van Ween Grab. A sampling site deemed representative of the majority of the lake was selected. The sampling site was covered during the summer, primarily by Chara vulgaris and Phragmites australis, cattails (Typha domingensis Pers.), and two species of rush (Juncus spp.).

Lake water samples were collected from 0 to $10 \mathrm{~cm}$ above the sediment-water interface. The temperature, dissolved oxygen (DO) concentration and $\mathrm{pH}$ of the overlying water were measured onsite.

\section{Analytical methods}

\section{Sediment samples and procedure}

All samples were stored at $4^{\circ} \mathrm{C}$ before laboratory experiments and analyses. All analyses and extractions were done in triplicate, comprising the sediment composition determined for air-dried sediment samples homogenized by grinding (Kacar, 1995). The dried sediments $\left(105^{\circ} \mathrm{C}, 24 \mathrm{~h}\right)$ were analysed spectrophotometrically for TP after digestion in a mixture of oxidizing acids. Sediment phosphorus fractionations were determined with the method of Hieltjes and Lijklema (1980), including (i) loosely sorbed phosphorus $\left(\mathrm{CO}_{3} \approx \mathrm{P}\right)$, extracted for $2 \mathrm{~h}$ with $1 \mathrm{M} \mathrm{NH} \mathrm{NH}_{4} \mathrm{Cl}$, (ii) iron-plusaluminium-bound phosphorus $(\mathrm{Fe}+\mathrm{Al} \approx \mathrm{P}$ ), extracted for $17 \mathrm{~h}$ with $0.1 \mathrm{~N} \mathrm{NaOH}$, and (iii) calcium-bound phosphorus $(\mathrm{Ca} \approx \mathrm{P})$, extracted for $24 \mathrm{~h}$ with $0.5 \mathrm{~N} \mathrm{HCl}$. Organicbound phosphorus $(\mathrm{Org} \approx \mathrm{P}$ ) was calculated as the difference between TP and the sum of the inorganic fractions. The sediment water content was determined by drying at $110^{\circ} \mathrm{C}$ for $16 \mathrm{~h}$, and loss on ignition (LOI) was determined by the loss of weight during ignition at $550^{\circ} \mathrm{C}$ for $2 \mathrm{~h}$. The total iron concentration was measured with Atomic Adsorption/Flame Emission Spectroscopy (APHA, 1995). Sediment total nitrogen was determined using the Dumas Method. 
All parameters were measured for all sections of the sediment and reported on a dryweight basis. Concentration profiles were used to calculate the diffusive flux of soluble reactive phosphorus (SRP, given as P-release rates) towards the sediment surface, based on Fick's first law of diffusion (Shaw and Prepas, 1990). The concentrations of TP and soluble reactive phosphorus were measured according to the method outlined in APHA (1995).

\section{Overlying water and sediment pore water analysis}

Sediment pore water was obtained by vacuum filtration of the sediment samples (Eckert et al., 1997), and sediment overlying water was obtained by siphoning from the water $10 \mathrm{~cm}$ above the sediment. Water from these samples was analyzed in duplicate for soluble reactive $\mathrm{P}$ (SRP) (APHA, 1995).

\section{Phosphorus release estimation}

Potential phosphorus release from the sediment into the lake water by molecular diffusion was calculated by Berner (1980) (Shaw and Prepas, 1990):

$$
\text { Flux }=\varphi \cdot D \cdot Q^{-2} \cdot d c / d x \cdot 86400
$$

in which flux $=$ SRP flux across the sediment-water interface $\left(\right.$ in $\left.\mathrm{mg} \mathrm{m}^{-2} \mathrm{~d}^{-1}\right)$

$\varphi=$ the water content by volume (dimensionless)

$\mathrm{D}=$ molecular diffusion coefficient (varies according to temperature)

$\mathrm{Q}^{2}=$ tortuosity term $(\varphi-0.8$; (Shaw and Prepas, 1990))

$\mathrm{dc} / \mathrm{dx}=$ the SRP gradient across the sediment-water interface $\left(\mathrm{mg} \mathrm{m}^{-4}\right) 86400=$ the factor to convert s to $\mathrm{d}$.

\section{Statistical analyses}

Statistical evaluation of data including some physiochemical properties of the sediment, determination of fractional phosphate concentrations, and analyses of the sediment overlying water were performed using the Windows Minitab and MStat databases according to the method established by Kesici and Kocabaş (2007).

\section{Results}

The differences between the months and stations with regard to the averages of total nitrogen, total organic carbon, total phosphorus, phosphorus fractions, total iron, organic matter concentrations and water contents found in the littoral sediment of Mogan Lake in April, July and October 2015 and January 2016 were found to be statistically significant $(\mathrm{p}<0.05)$ (Table 1, Figure 2). Information regarding the sediment composition at each of the Mogan Lake stations is shown in Table 2. The sediment composition at both stations was classified as rich in clay and loam (CL).

Differences between the months and stations with regard to the averages for water temperature, dissolved oxygen, $\mathrm{pH}$, total filterable orthophosphate concentrations in the overlying water and SRP concentrations in the sediment pore water of Mogan Lake in the months of April, July and October 2015 and January 2016 were found to be statistically significant $(\mathrm{p}<0.05)($ Table 3$)$. 
Table 1. Seasonal and spatial variations of sediment total nitrogen (TN), total organic carbon (TOC), total iron (TFe), Loss on ignition (LOI) and water content in Mogan Lake (Mean value \pm standard deviation, $N=4$ )

\begin{tabular}{|c|c|c|c|}
\hline Properties & Sample sites & 1 & 2 \\
\hline $\begin{array}{c}\mathrm{TN} \\
\left(\mu \mathrm{g} \mathrm{gDW}^{-1}\right)\end{array}$ & $\begin{array}{c}\text { April } 2015 \\
\text { July } 2015 \\
\text { October } 2015 \\
\text { January } 2016\end{array}$ & $\begin{array}{c}3350.00 \pm 125.83^{\mathrm{CHa}^{*}} \\
6250.00 \pm 537.74^{\mathrm{Aa}} \\
3975.00 \pm 131.50^{\mathrm{Cb}} \\
5175.00 \pm 4.87^{\mathrm{Ba}}\end{array}$ & $\begin{array}{c}3250.00 \pm 150.00^{\mathrm{Ca}} \\
6325.00 \pm 309.23^{\mathrm{Aa}} \\
6175.00 \pm 137.69^{\mathrm{Aa}} \\
4150.00 \pm 86.60^{\mathrm{Bb}}\end{array}$ \\
\hline $\begin{array}{c}\text { TOC } \\
\left(\mu \mathrm{g} \mathrm{gDW}^{-1}\right)\end{array}$ & $\begin{array}{c}\text { April2015 } \\
\text { July } 2015 \\
\text { October } 2015 \\
\text { January } 2016\end{array}$ & $\begin{array}{c}63550.00 \pm 425.25^{\mathrm{BCa}} \\
79675.00 \pm 5549.38^{\mathrm{ABa}} \\
64750.00 \pm 3547.42^{\mathrm{BCa}} \\
69600.00 \pm 248.33^{\mathrm{ABb}}\end{array}$ & $\begin{array}{c}58850.00 \pm 2465.94^{\mathrm{Ba}} \\
77700.00 \pm 3966.32^{\mathrm{Aa}} \\
79250.00 \pm 1156.50^{\mathrm{Aa}} \\
75550.00 \pm 847.05^{\mathrm{Aa}}\end{array}$ \\
\hline $\begin{array}{c}\mathrm{TFe} \\
\left(\mathrm{mg} \mathrm{gDW}^{-1}\right)\end{array}$ & $\begin{array}{c}\text { April2015 } \\
\text { July } 2015 \\
\text { October } 2015 \\
\text { January } 2016 \\
\end{array}$ & $\begin{array}{l}3.313 \pm 0.040^{\mathrm{Aa}} \\
1.718 \pm 0.111^{\mathrm{Bb}} \\
1.913 \pm 0,030^{\mathrm{Bb}} \\
3.098 \pm 0.069^{\mathrm{Aa}}\end{array}$ & $\begin{array}{l}1.608 \pm 0.022^{\mathrm{Cb}} \\
3.415 \pm 0.026^{\mathrm{Aa}} \\
3.238 \pm 0.010 \mathrm{~B}^{\mathrm{a}} \\
3.275 \pm 0.051^{\mathrm{Ba}}\end{array}$ \\
\hline $\begin{array}{l}\text { LOI } \\
(\%)\end{array}$ & $\begin{array}{c}\text { April2015 } \\
\text { July } 2015 \\
\text { October } 2015 \\
\text { January } 2016\end{array}$ & $\begin{array}{l}20.94 \pm 1.41^{\mathrm{Aa}} \\
10.10 \pm 0.13^{\mathrm{Ab}} \\
10.17 \pm 0.77^{\mathrm{Bb}} \\
12.58 \pm 0.22^{\mathrm{Ba}}\end{array}$ & $\begin{array}{c}15.83 \pm 0.08^{\mathrm{Ab}} \\
9.05 \pm 0.04^{\mathrm{Ba}} \\
15.54 \pm 0.15^{\mathrm{Aa}} \\
11.88 \pm 0.14^{\mathrm{Bb}}\end{array}$ \\
\hline $\begin{array}{c}\text { Water content } \\
(\%)\end{array}$ & $\begin{array}{c}\text { April2015 } \\
\text { July } 2015 \\
\text { October } 2015 \\
\text { January } 2016\end{array}$ & $\begin{array}{l}88.25 \pm 0.48^{\mathrm{Aa}} \\
76.50 \pm 0.65^{\mathrm{Ba}} \\
87.50 \pm 0.54^{\mathrm{Aa}} \\
88.25 \pm 0.48^{\mathrm{Aa}}\end{array}$ & $\begin{array}{l}85.00 \pm 0.41^{\mathrm{Ab}} \\
77.00 \pm 0.41^{\mathrm{Ba}} \\
86.50 \pm 1.19^{\mathrm{Aa}} \\
87.25 \pm 1.10^{\mathrm{Aa}}\end{array}$ \\
\hline
\end{tabular}

${ }^{*}$ The different lower-case letters in the same row show the differences between stations $(\mathrm{p}<0.05)$

\#The different upper-case letters in the same column show the differences between months $(\mathrm{p}<0.05)$

Table 2. Spatial sediment grain size in Mogan Lake

\begin{tabular}{c|c|c|c|}
\hline Properties & & \multicolumn{2}{|c|}{ Sample sites } \\
\hline \multirow{4}{*}{ Grain size $(\boldsymbol{\mu m})$} & Clay (<4) & $\mathbf{1}^{\text {st }}$ station & $\mathbf{2}^{\text {nd }}$ station \\
& Silt (4-63) & 68.99 & 65.12 \\
& Sand (63-500) & 19.72 & 22.33 \\
& Class & 11.29 & 12.55 \\
& Clay+loam(CL) & Clay+loam (CL) \\
\hline
\end{tabular}




$$
-710 \text { - }
$$

Table 3. Seasonal and spatial variations of sediment overlying water's water temperature, dissolved oxygen, $p H$, and SRP with sediment porewater SRP in Mogan Lake (Mean value \pm standard deviation, $N=4$ )

\begin{tabular}{|c|c|c|c|}
\hline Properties & $\underbrace{\text { Sample sites }}_{\text {Months }}$ & 1 & 2 \\
\hline \multirow{4}{*}{$\begin{array}{l}\text { Water temperature } \\
\left({ }^{\circ} \mathbf{C}\right)\end{array}$} & April2015 & $22.08 \pm 0.05^{\mathrm{B \#} \mathrm{a}^{*}}$ & $21.88 \pm 0.05^{\mathrm{Ba}}$ \\
\hline & July 2015 & $26.68 \pm 0.03^{\mathrm{Aa}}$ & $25.25 \pm 0.03^{\mathrm{Ab}}$ \\
\hline & October 2015 & $10.08 \pm 0.03^{\mathrm{Ca}}$ & $10.23 \pm 0.05^{\mathrm{Ca}}$ \\
\hline & January 2016 & $3.33 \pm 0.05^{\mathrm{Da}}$ & $3.48 \pm 0.03^{\mathrm{Da}}$ \\
\hline \multirow{4}{*}{$\underset{\left(\mathbf{m g ~ L}^{-1}\right)}{\mathrm{DO}_{2}}$} & April2015 & $9.88 \pm 0.23^{\mathrm{Bb}}$ & $13.45 \pm 0.10^{\mathrm{Ba}}$ \\
\hline & July 2015 & $11.20 \pm 0.11^{\mathrm{Ab}}$ & $15.72 \pm 0.02^{\mathrm{Aa}}$ \\
\hline & October 2015 & $6.31 \pm 0.00^{\mathrm{Ca}}$ & $5.90 \pm 0.01^{\mathrm{Db}}$ \\
\hline & January 2016 & $9.93 \pm 0.03^{\mathrm{Bb}}$ & $10.23 \pm 0.04^{\mathrm{Ca}}$ \\
\hline \multirow{4}{*}{ pH } & April2015 & $9.42 \pm 0.01^{\mathrm{Ab}}$ & $9.56 \pm 0.02^{\mathrm{Aa}}$ \\
\hline & July 2015 & $8.88 \pm 0.01^{\mathrm{Bb}}$ & $9.46 \pm 0.05^{\mathrm{Aa}}$ \\
\hline & October 2015 & $7.99 \pm 0.00^{\mathrm{Db}}$ & $8.30 \pm 0.01^{\mathrm{Ba}}$ \\
\hline & January 2016 & $8.13 \pm 0.00^{\mathrm{Ca}}$ & $7.72 \pm 0.06^{\mathrm{Ca}}$ \\
\hline \multirow{4}{*}{$\begin{array}{l}\text { OW SRP } \\
\left(\mathbf{m g ~ m}^{-3}\right)\end{array}$} & April2015 & $39.68 \pm 0.79^{\mathrm{Bb}}$ & $80.16 \pm 0.79^{\mathrm{Aa}}$ \\
\hline & July 2015 & $40.48 \pm 0.79^{\mathrm{Ba}}$ & $17.46 \pm 0.92^{\mathrm{Cb}}$ \\
\hline & October 2015 & $65.08 \pm 0.91^{\mathrm{Aa}}$ & $38.89 \pm 2.71^{\mathrm{Bb}}$ \\
\hline & January 2016 & $62.70 \pm 7.82^{\mathrm{Aa}}$ & $78.57 \pm 3.27^{\mathrm{Aa}}$ \\
\hline \multirow{4}{*}{$\begin{array}{l}\text { PW SRP } \\
\left(\mathrm{mg} \mathrm{m}^{-3}\right)\end{array}$} & April2015 & $817.22 \pm 2.92^{\mathrm{Ba}}$ & $353.89 \pm 10.52^{\mathrm{Cb}}$ \\
\hline & July 2015 & $412.78 \pm 4.19^{\mathrm{Cb}}$ & $196.67 \pm 1.93^{\mathrm{Da}}$ \\
\hline & October 2015 & $836.11 \pm 7.39^{\mathrm{Ba}}$ & $809.45 \pm 1.06^{\mathrm{Aa}}$ \\
\hline & January 2016 & $960.56 \pm 11.24^{\mathrm{Aa}}$ & $411.67 \pm 8.72^{\mathrm{Bb}}$ \\
\hline
\end{tabular}

*The different lower-case letters in the same row show the differences between stations $(\mathrm{p}<0.05)$

\#The different upper-case letters in the same column show the differences between months $(\mathrm{p}<0.05)$

a)

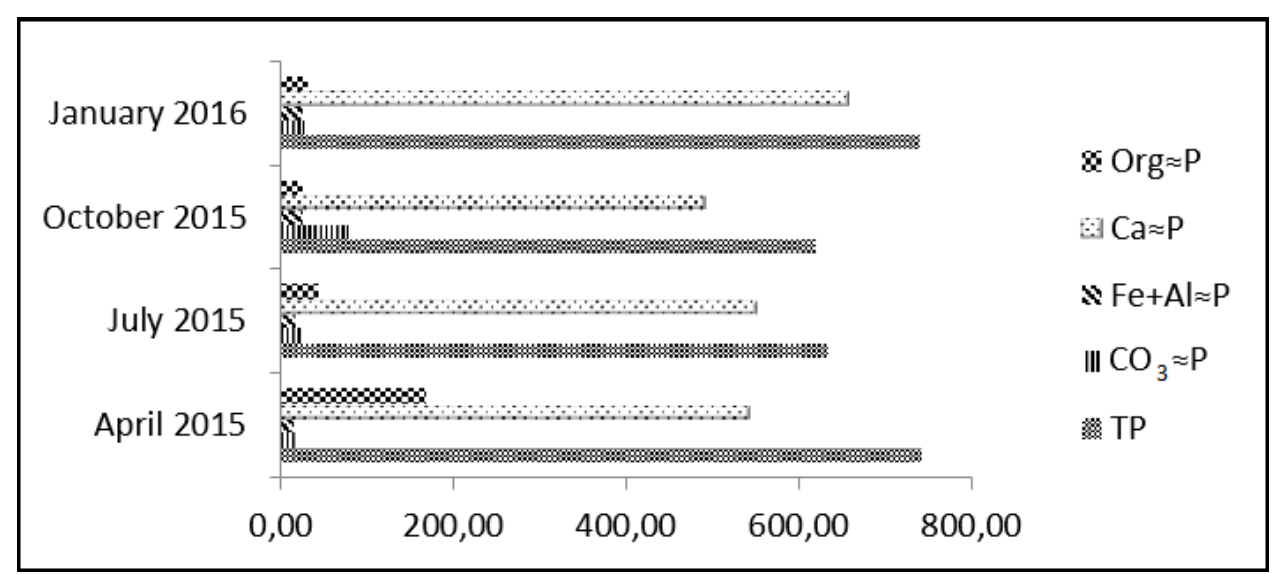


b)

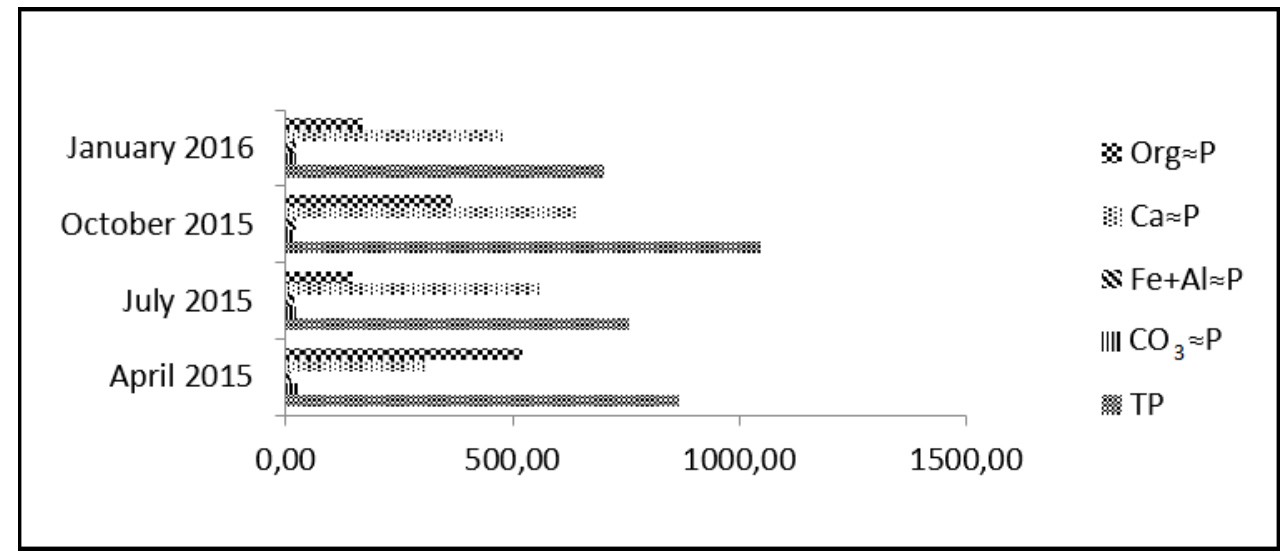

Figure 2. Seasonal variation of sediment phosphorus fractional composition $\left(\mu g g^{-1} D W^{-1}\right)$ in $1^{\text {st }}$ station (a) and in $2^{\text {nd }}$ station (b) of Lake Mogan

The average values for phosphorus release were calculated every month at each station during the entire research period. The phosphorus release values from the sediment varied between $0.1754-1.1249 \mathrm{mg} \mathrm{m}^{-2} \mathrm{day}^{-1}$, with the lowest value measured in July at the $2^{\text {nd }}$ station and the highest value seen in January at the $1^{\text {st }}$ station (Figure 3 ).

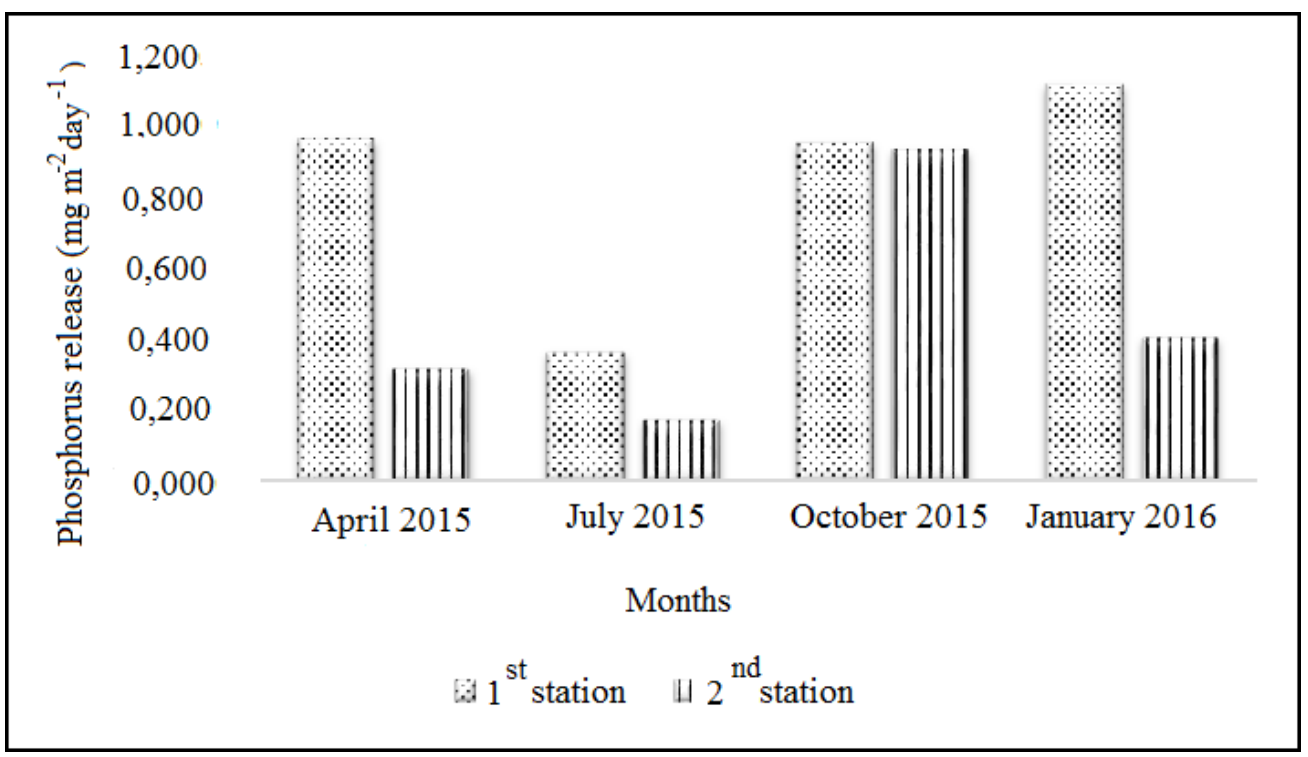

Figure 3. Monthly and spatially phosphorus release in lake Mogan

In Figures 4, 5 comparison of the present study regarding some sediment chemical composition (total phosphorus, phosphorus fractions, organic material and total iron) with some earlier study data (Topçu and Pulatsü 2008; Pulatsü et al., 2009) considering the common station was presented.

The differences of sediment porewater and sediment overlying water SRP concentrations between the current study and the earlier researches could be followed in Figure 6 notwithstanding, the comparative phosphorus release estimations of the present and the earlier data were shown in Figure 7. 


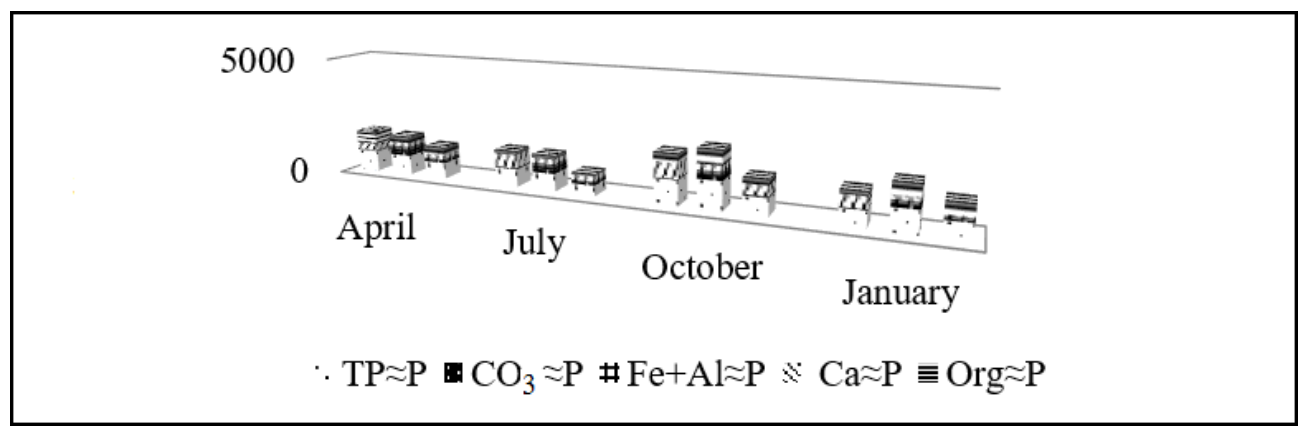

Figure 4. Monthly mean concentrations of phosphorus fractional composition $\left(\mu \mathrm{g} \mathrm{g}^{-1} \mathrm{DW} \mathrm{W}^{1}\right)$ in Mogan Lake (1 $1^{\text {st }}$ bar: Present study, $2^{\text {nd }}$ bar: Topçu and Pulatsü (2008), $3^{\text {rd }}$ bar: Pulatsü et al. (2009)

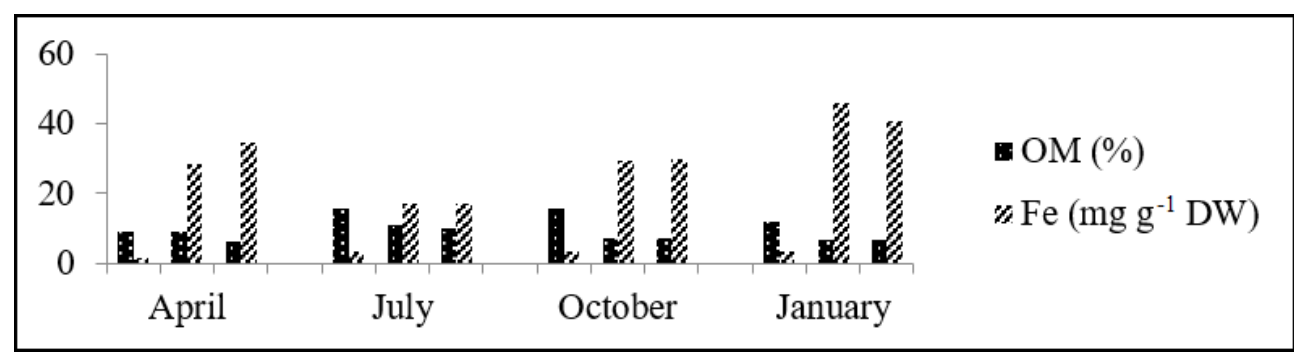

Figure 5. Monthly mean concentrations of sediment iron concentration and organic material in Mogan Lake ( $1^{\text {st }}$ bar group: Present study, $2^{\text {nd }}$ bar group: Topçu and Pulatsü (2008), $3^{\text {rd }}$ bar group: Pulatsü et al. (2009)

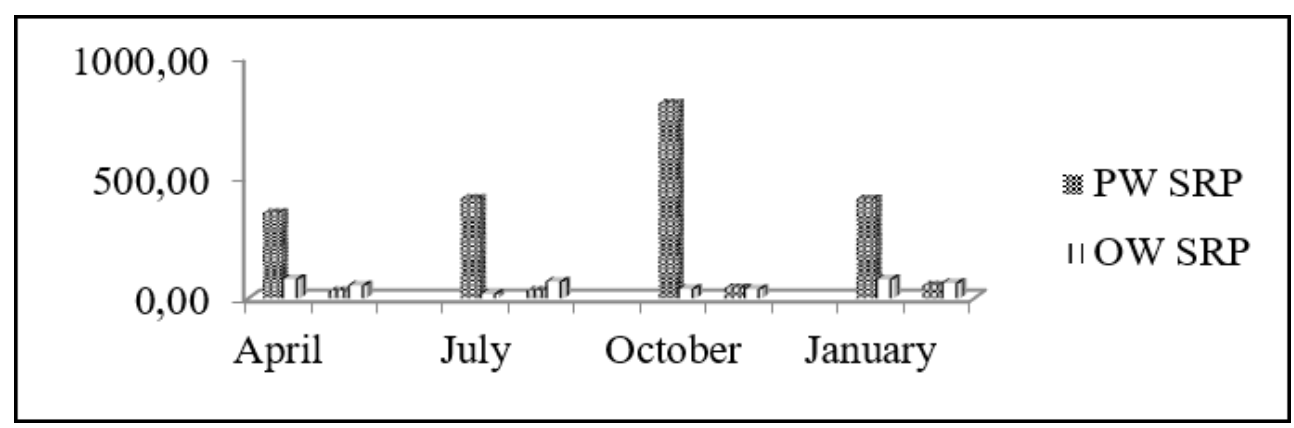

Figure 6. Monthly mean concentrations of porewater SRP $\left(\mathrm{mg} \mathrm{m}^{-3}\right)$ and overlying water SRP $\left(\mathrm{mg} \mathrm{m}^{-3}\right)$ in Mogan Lake ( $1^{\text {st }}$ bar: Present study, $2^{\text {nd }}$ bar: Topçu and Pulatsü (2008)

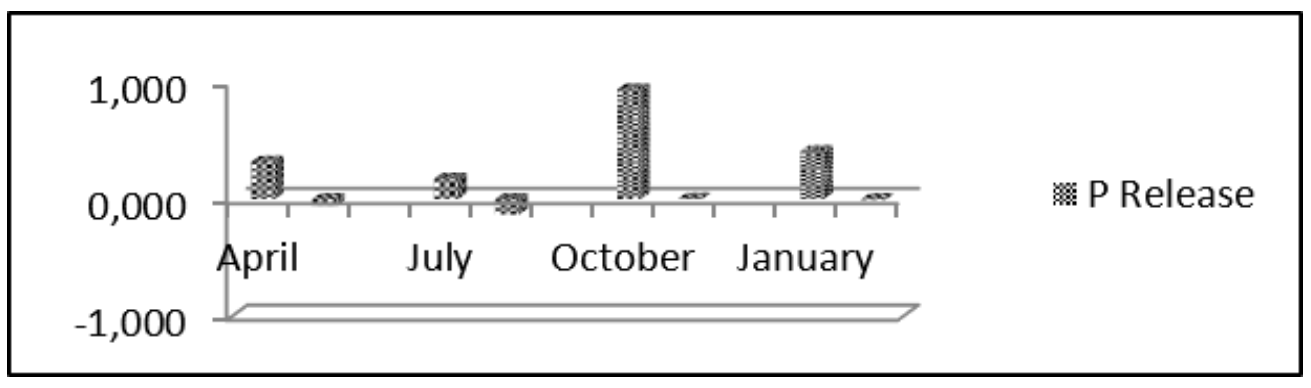

Figure 7. Monthly mean concentrations of phosphorus release estimation $\left(\mathrm{mg} \mathrm{m}^{-2} \mathrm{day}^{-1}\right)$ in Mogan Lake ( $1^{\text {st }}$ bar: Present study, $2^{\text {nd }}$ bar: Topçu and Pulatsü (2008) 


\section{Discussion}

In a large-scale lake restoration study on European lakes, it was determined that sediments with phosphorus content $>1 \mathrm{mg} \mathrm{P} \mathrm{g} \mathrm{DW}^{-1}$ generally show sediment $\mathrm{P}$ release, whereas $\mathrm{P}$ retention may be expected for $\mathrm{P}$ content $<1 \mathrm{mg} \mathrm{P} \mathrm{g} \mathrm{DW}{ }^{-1}$ (Kelderman et al., 2005). Accordingly, the averge TP concentration in the sediment of Mogan Lake $\left(843 \mu \mathrm{g} \mathrm{gDW}^{-1}\right)$ is thought to quantitatively demonstrate phosphorus retention by the sediment. The fact that the highest total phosphorus values at both research stations in Mogan Lake were detected in the autumn months supports the findings of Spears et al. (2007) that heavy macrophyte concentration and planktonic detritus are factors leading to high sediment phosphorus levels in the autumn.

Eutrophic Bear Lake (Michigan) is characterized by elevated TP concentrations (Steinman and Ogdahl 2015). There are several possibilities why internal P loading is not more problematic in Bear Lake like this current study; given that the sediments have relatively high TP concentrations. Second reason was the well-mixed water column keeping the lake relatively free of hypoxic conditions. The final reason was the high sediment TFe concentration. Mogan Lake's findings coincide with the above researcher's reasons for the low P internal loading in Bear Lake.

When the findings of Boyd et al. (1994) and Istvanovics (1994) are taken into account, it can be seen that in Mogan Lake's sediment, the variation of the quantity of organic matter between 9 and $16 \%$, the total carbon concentration $(7.11 \%)$ and the limestone sediment composition are important elements contributing to phosphorus retention in the sediment. Phosphorus chemistry in aquatic ecosystems is generally controlled by phosphorus and iron interactions. In this study sediment $\mathrm{TFe}$ concentrations range (2-3 $\mathrm{mg} \mathrm{g} \mathrm{DW}^{-1}$ ) was lower than both Topçu and Pulatsü (2008) and Pulatsü et al. (2009)'s findings (17-46 $\mathrm{mg} \mathrm{g} \mathrm{DW}^{-1}$ ), nevertheless, LOI values (9-16 $\%$ ) respecting the present study were found to be higher than the previous studies data (6-11\%) in Mogan Lake. When it comes to the levels of iron and organic matter in the sediment of Mogan Lake, it can be said that, in line with Temporetti and Pedrozo's (2000) findings, the sediment's organic matter plays a more important role than its iron concentration in controlling phosphorus release from the sediment.

Moreover, while dissolved oxygen concentrations varied between $6.31-15.72 \mathrm{mg} \mathrm{L}^{-1}$ during the study, they never fell to a value low enough to instigate phosphorus release from the sediment into the lake water. Besides this, it can be said that while the $\mathrm{pH}$ values found (7.72 - 9.56) were close to the range reported by Lehronta and Heiskanen (2003) $(\mathrm{pH}>8.5-10)$, this in itself is not enough to affect phosphorus retention.

Phosphorus fractionation is a good way to understand phosphorus origins and transformation in the sediments in the shallow lakes. Sediment phosphorus fraction forms are potentially mobile and may eventually be released into the lake water (Yuan et al., 2014). The order of phosphorus fractions that are effective in preventing phosphorus release from the sediment into the water in Mogan Lake is $\mathrm{Ca} \approx \mathrm{P}>\mathrm{Org} \approx \mathrm{P}>\mathrm{CO}_{3} \approx \mathrm{P}>\mathrm{Fe}+\mathrm{Al} \approx \mathrm{P}$ except April. Topçu and Pulatsü (2008) reported the sequence of fractional distribution of phosphorus in the sediment of the same lake, regarding the general mean monthly values, as $\mathrm{Org} \approx \mathrm{P}>\mathrm{Ca} \approx \mathrm{P}>\mathrm{Fe}+\mathrm{Al} \approx \mathrm{P}>\mathrm{CO}_{3} \approx \mathrm{P}$. Among these, it can be told that the fractions with the greatest effect on phosphorus retention in the sediment are calcium-bound and organically-bound phosphorus fractions in general. In this context, considering the common station sediment phosphorus fractional composition showed an irregular distribution. 
Taihu Lake (in the southeast part of the Yangtze River Delta), a large shallow lake, serves as an important source for drinking and irrigation water, moreover a great amount of wastewater has been discharged into the lake with increased urbanization, industrial and agricultural activities in the watershed and the fractional composition of sediment phosphorus was in the descending order: $\mathrm{Ca}$-bound $\mathrm{P}>\mathrm{Fe}$ bound $\mathrm{P}>$ Organic P>Labile P (Yuan et al., 2014). Mogan Lake's sediment important phosphorus fraction coincides with the above researcher's data. It is thought that Mogan Lake's basin of limestone rock and the apatite phosphorus fractions $(\mathrm{Ca} \approx \mathrm{P})$ originating from this rock promote phosphorus retention by the sediment. However, carbonate-bound phosphorus fractions $\left(\mathrm{CO}_{3} \approx \mathrm{P}\right)$ play an especially important role in clay-rich sediments, and thus represent an important phosphorus fraction in phosphorus retention (Shresta and Lin 1996; Dittrich et al., 2013). The clay-rich composition of the sediment at both of the stations in this study ( $65 \%$ and $69 \%$ ) increased the role of the $\mathrm{CO}_{3} \approx \mathrm{P}$ fractions in keeping phosphorus release at a low level.

The concentration level of pore water SRP in this study was very high in comparison to Topçu and Pulatsü (2008)'s findings. Moreover, overlying water SRP concentrations of this study was found to be generally higher than the previous study except July. The lowest phosphorus release values in Mogan Lake were measured in July, and the fact that SRP values in the sediment pore water did not show an increase seem to support this finding. SRP values in the sediment pore water in this study reached their maximum values $\left(960.56 \mathrm{mg} \mathrm{m}^{-3}\right.$ ) in January 2016 due to factors such as death and decay of macrophytes. The increase, especially during the summer, in phosphorus concentrations in the sediment pore water in shallow lakes is a result of phosphorus loading from the sediment (Spears et al., 2007). The fact that SRP concentrations in the overlying water in Mogan Lake were at their highest during the spring and at their lowest values (17.46

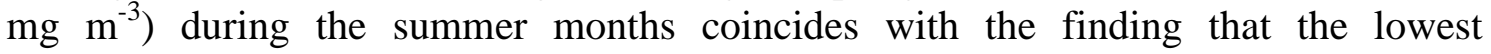
phosphorus release from the sediment was seen during the summer.

Zamparas and Zacharias (2014) stated that priorly the perpetuity to proceed to a restoration method, like monitoring of external and internal nutrient loads should initially be carried out. In this manner the authors believe that defining the reference conditions of the ecosystem and choosing which method to use in order to have the desired results will be more easier. Although no routine management strategy exists for Mogan Lake, the local government has carried out efforts such as reducing the external pollutant load and diverting running water into the lake to accelerate the flushing of the lake water, and has also occasionally carried out macrophyte harvesting and dredging operations. Dredging alone, one of the management applications in Mogan Lake, without the reduction of external phosphorus loading will result in a system eventually returning to its prior condition agrees with the findings of Smolders et al. (2006) and Sharpley et al. (2013).

Phosphorus fluxes between the water column and the sediment layer were largely driven by the redox chemistry of sediment and dissolved oxygen depletion in bottom waters, which is biologically mediated by heterotrophic oxygen consumption and physically controlled by water column structure (Giles et al., 2016). In Mogan Lake phosphorus release values from the sediment were found to be extremely low, varying

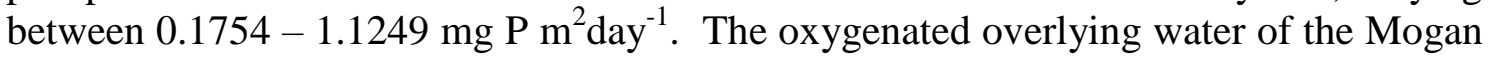
Lake was one of the effective factors leading to a low P flux as the above researchers' expressions. However, these values were higher than the phosphorus release values measured between July 2004 and June 2005 in the same lake by Topçu and Pulatsü 
(2008). The fact that phosphorus release in the lake has increased over the past ten years but still remains at a generally low level together with the above-mentioned management activities in Mogan Lake.

\section{Conclusion}

In conclusion, it is clear that the macrophyte harvesting and dredging operations still being undertaken by the local government with the purpose of controlling eutrophication have not had a strong effect on the sediment-sediment overlying water phosphorus mobility. Moreover, considering the last 10 years study, related to the release of phosphorus from the sediment to the water of Mogan Lake, have risen limitedly but does not seem to be extremely high enough to effect the nutrient level of the lake. Consequently, in shallow eutrophic systems such as this one, hotspots of phosphorus accumulation in the sediment are subject to complex interactions with mainly anthropogenic external sources. Nevertheless in order to control the eutrophication process in Lake Mogan, the primary goal should be to determine the adsorption capacity of the sediment in order to estimate the critical internal phosphorus load and take earlier precautions, and the second goal should be to apply a monitoring program on the lake's trophic level.

Acknowledgments. This research is a part of the study which was supported by Turkish Scientific and Technological Research Council TUBITAK Project No. TOVAG: 115Y375).

\section{REFERENCES}

[1] APHA (1995). Standart Methods for the Examination of Water and Wastewater $\left(19^{\text {th }}\right.$ Edition). - Jonn D., Ducas Co., USA, 1193.

[2] Boşgelmez, A., Boşgelmez, İ. İ., Savcı, A. E., Aldemir, A., Gürpınar, E., Mutlu, B., Topaloğlu, S., Ege, M., Çiçek, N. (2005): Ankara-Gölbaşı and Centaurea tchihatcheffii. Centaurea tchihatcheffii Ankara-Gölbaşı Sevgi Çiçeği, Ankara. - Ankara Turkey Press, 131-178.

[3] Boyd, C. E., Taner, M. E., Madkour, M., Masuda, K. (1994): Chemical Characteristics of Bottom Soils From Freshwater and Brackishwater Aquaculture Ponds. - Journal of the World Aquaculture Society 25 (4): 517-534. http://dx.doi.org/10.1111/j.17497345.1994.tb00821.x.

[4] Christophoridis, C., Fytianos, K. (2006): Conditions Affecting the Release of Phosphorus from Surface Lake Sediments. - J. Environ. Qual. 35: 1181-1192. http://dx.doi.org/10.2134/jeq2005.0213.

[5] Dittrich, M., Chesnyuk, A., Gudimov, A., McCulloch J., Quazi, S., Young, J., Winter, J., Stainsby, E., Arhonditsis, G. (2013): Phosphorus Retention in a Mesotrophic Lake Under Transient Loading Conditions: Insights from a Sediment Phosphorus Binding Form Study. - Water Research 47: 1433-1447.

[6] Eckert, W., Nishri, A., Parparova, R. (1997): Factors Regulating the Flux of Phosphate at the Sediment-Water Interface of a Subtropical Calcareous Lake: A Simulation Study With Intact Sediment Cores. - Water, Air and Soil Pollution 99: 401-409. http://dx.doi.org/10.1023/A:1018335305539.

[7] Fakığlu, Ö., Pulatsü, S. (2005): Mogan Gölü’nde (Ankara) Bazı Restorasyon Önlemleri Sonrası Dış Kaynaklı Fosfor Yükünün Belirlenmesi. - Yüzüncü Yıl Üniversitesi Ziraat Fakültesi Tarım Bilimleri Dergisi (J. Agric. Sci.) 15(1): 63-69 (in Turkish). 
[8] Giles, C. D., Isles, P. D. F., Manley, T., Xu, Y., Druschel, G. K., Schroth, A. W. (2016): The mobility of phosphorus, iron, and manganese through the sediment-water continuum of a shallow eutrophic freshwater lake under stratified and mixed water-column conditions. - Biogeochemistry 127:15-34. http://dx.doi.org/10.1007/s10533-015-0144-x.

[9] Hieltjes, A. H. M., Lijklema, L. (1980): Fractionation of Inorganic Phosphates in Calcareous Sediments. - J. Environ. Qual. 9 (3): 405-407.

[10] Istvanovics, V. (1994): Fractional Composition, Adsorbtion and Release of Sediment Phosphorus in the Kiss-Balaton Reservoir. - Wat. Res. 28 (3): 717-726. http://dx.doi.org/10.1016/0043-1354(94)90152-X.

[11] Kaçar, B. (1995): Bitki ve Toprağın Kimyasal Analizleri 3: Toprak Analizleri. - Ankara Üniversitesi Ziraat Fakültesi Eğitim Araştırma ve Geliştirme Vakfı Yayınları, No: 3. Ankara, Turkey, AZV Press, 705. (in Turkish).

[12] Kelderman, P., Weil, Z., Maessen, M. (2005): Water and Mass Budgets for Estimating Phosphorus Sediment-Water Exchange in Lake Taihu (China P. R.). - Hydrobiologia 544: 167-175. http://dx.doi.org/10.1007/s10750-005-0542-5.

[13] Kesici, T., Kocabaş, Z. (2007): Biyoistatistik. - Ankara Üniversitesi Eczacıllk Fakültesi. Yayin No: 94, Ankara.

[14] Lehtoranta, J., Heiskanen, A. S. (2003): Dissolved Iron-Phosphate Ratio as an Indicator of Phosphate Release to Oxic Water Of The Iner and Outer Coastal Baltic Sea. Hydrobiologia 492: 69-84. http://dx.doi.org/10.1023/A:1024822013580.

[15] Madura K., Gołdyn R. (2009): Internal Loading of Phosphorus from Sediments of Swarzędzkie Lake (Western Poland). - Polish J. of Environ. Stud. 18 (4): 635-643.

[16] Pu, X., Cheng, H., Tysklind, M., Xie, J., Lu, L., Yang, S. (2017): Occurrence of water phosphorus at the water-sediment interface of a freshwater shallow lake: Indications of lake chemistry Shengtian. - Ecological Indicators (2017) 81:443-452.

[17] Pulatsü, S., Topçu, A., Kırkağaç, M., Köksal, G. (2008): Sediment Phosphorus Characteristics in the Clearwater State of Lake Mogan, Turkey. - Lakes \& Reservoirs: Research and Management 13: 197-205. http://dx.doi.org/10.1111/j.14401770.2008.00369.x

[18] Pulatsu, S., Topcu, A. (2009): Seasonal and Vertical Distributions of Porewater Phosphorus and Iron Concentrations in a Macrophyte-Dominated Eutrophic Lake. Journal of Environmental Biology 30 (5): 801-806.

[19] Sharpley, A., Jarvie, H. P., Buda, A., May, L., Spears, B., Kleinman, P. (2013): Phosphorus Legacy: Overcoming the Effects of Past Management Practices to Mitigate Future Water Quality Impairment. - Journal of Environmental Quality 42: 1308-1326. http://dx.doi.org/10.2134/jeq2013.03.0098.

[20] Shaw, J. F. H., Prepas, E. E. (1990): Relationships Between Phosphorus in Shallow Sediments and in the Trophogenic Zone of Seven Alberta Lakes. - Wat. Res. 24 (5): 551556. http://dx.doi.org/10.1016/0043-1354(90)90186-A.

[21] Shrestha, M. K., Lin, C. K. (1996): Determination of Phosphorus Saturation Level in Relation to Clay Content in Formulated Pond Muds. - Aquacultural Engineering 15 (6): 441-459. http://dx.doi.org/10.1016/S0144-8609(96)01007-2.

[22] Smolders, A. J. P., Lamers, L. P. M., Lucassen, E. C. H. E. T., Van Der Velde, G., Roelofs J. G. M. (2006): Internal Eutrophication: How It Works and What To Do About It - A Review. - Chemistry and Ecology 22 (2): 93-111. http://dx.doi.org/10.1080/02757540600579730.

[23] Søndergaard, M., Jeppesen, E, Lauridsen, T. L., Skov, C., Van Nes, Eh., Roijackers, R., Lammens, E., Portielje, R. (2007): Lake Restoration: Successes, Failures and Long-Term Effects. - Journal of Applied Ecology 44 (6): 1095-1105. http://dx.doi.org/10.1111/j.1365-2664.2007.01363.x.

[24] Spears B. M., Carvalho L., Perkins R., Kirika A., David E., Paterson M. (2007): Sediment Phosphorus Cycling in a Large Shallow Lake: Spatio-Temporal Variation in Phosphorus 
Pools and Release. - Hydrobiologia 584: 37-48. http://dx.doi.org/10.1007/s10750-0070610-0.

[25] Steinman, A. D., Ogdahl, M. E. (2015): TMDL Reevaluation: Reconciling Internal Phosphorus Load Reductions in a Eutrophic Lake. - Lake and Reservoir Management, 31:115-126.

[26] Temporetti, P.F., Pedrozo, F.L. (2000): Phosphorus Release Rates From Freshwater Sediments Affected by Fish Farming. - Aquaculture 31: 447-455. http://dx.doi.org/10.1046/j.1365-2109.2000.00465.x

[27] Topçu, A., Pulatsu, S. (2008): Phosphorus Fractions in Sediment Profiles of the Eutrophic Lake Mogan, Turkey. - Fresenius Environmental Bulletin 17 (2): 164-172.

[28] Watson, S. B., Miller, C., Arhonditsis, G., Boyer, G .L., Carmichael, W., Charlton, M. N., Confesor, R., Depew, D. C., Höök, T. O., Ludsin, S. A., Matisoff, G., McElmurry, S. P., Murray, M. W., Richards, R. P., Rao, Y. R., Steffen, M. M., Wilhelm, S. W. (2016): The re-eutrophication of Lake Erken: Harmful Algal Blooms and Hypoxia. - Harmful Algae 56: 44-66.

[29] Yuan, H., An, S., Shen, J., Liu, E. (2014): The characteristic and environmental pollution records of phosphorus species in different trophic regions of Taihu Lake, China. - Environ Earth Sci. 71: 783-792. http://dx.doi.org/10.1007/s12665-013-2480-2.

[30] Zamparas, M., Zacharias, I. (2014): Restoration of Eutrophic Freshwater by Managing Internal Nutrient Loads. A Review. - Science of the Total Environment 496: 551-562. 